\title{
Structural behavior of CFST arch foots under pumping pressure of concrete infills
}

\author{
Xuehong Zhou', Haiyun Cheng ${ }^{2}$, Gang $\mathrm{Wu}^{3}$, Junlin $\mathrm{Zuo}^{4}$, Shangfu Peng ${ }^{5}$ \\ $1,4,5$ The Road and Bridge Engineering Company of the Fifth Engineering Group Co., Ltd. of China \\ Railway, Guangzhou, 511458, China \\ ${ }^{2}$ China Railway Guangzhou Group Co., Ltd., Guangzhou, 510000, China \\ ${ }^{3}$ Guangzhou Holding Company of the China Railway Siyuan Survey and Design Group Co., Ltd., \\ Guangzhou, 510600, China \\ ${ }^{1}$ Corresponding author \\ E-mail: ${ }^{1}$ tou1479@foxmail.com, ${ }^{2} h s h .1989 @ 163 . c o m,{ }^{3}$ crystalhsh@foxmail.com, ${ }^{4}$ heshhnu@hotmail.com, \\ 53011905633@qq.com
}

Received 8 May 2020; accepted 21 May 2020

DOI https://doi.org/10.21595/vp.2020.21479

Check for updates

Copyright $(C 2020$ Xuehong Zhou, et al. This is an open access article distributed under the Creative Commons Attribution License, which permits unrestricted use, distribution, and reproduction in any medium, provided the original work is properly cited.

\begin{abstract}
Prestressed concrete (PC) continuous girder-arch composite bridges, using concrete filled steel tubes (CFST) as the arch ribs to support the PC main girder, have gained their popularity in recently constructed large span bridges. The adoption of CFSTs brings many advantages, such as the concrete infill help to prevent the occurrence of local buckling in steel tubes, while the steel tubes can serve as framework for concrete core and strengthen the encased concrete. In order to achieve the above merits, the arch foots connecting the CFST arch ribs and PC girder are supposed to have sufficient strength and stiffness. However, the extensive use of CFST arch ribs showed that concrete cracking are commonly found at the arch foots. This paper studied the structural behavior of arch foot by employing a comprehensive numerical model. The influence of pumping pressure from concrete infill at construction stage on local stress of the arch foots was presented and discussed. The results indicated that the radial stress produced by pumping pressure at the joint zone squeezed the concrete around the arch foots, which resulted in significant hoop tensile stresses in the surrounding concrete. The outcomes of this study can provide technical support to improve the construction quality and structure stability, and optimize the construction procedures for this type of bridges.
\end{abstract}

Keywords: arch foot, CFST ribs, PC continuous girder, pumping pressure.

\section{Introduction}

Prestressed concrete (PC) continuous girder-arch composite bridge, consisting of PC box-girder and concrete filled steel tube (CFST) arch ribs, are very popular in the construction of railway bridges. One of the most significant advantages of this type of bridge is their enormous axial and bending stiffness [1]. The arch foot connecting CFST arch ribs and PC girder is critical for load transition between the members. In general, the arch foot should not only transfer axial, bending and shear forces from arch ribs to the supports, but also carry loads from the lateral direction of the PC girder [2]. The comprehensive local stress in arch foots results in its complex and in-regular geometrical configurations, which make the prediction of concrete cracking at the arch foot zone very difficult.

Concrete cracking at the arch foot harms the bearing capacity and durability of the girder-arch composite bridge. The inadequate consideration of affecting variables at initial design stage of the bridge would expose the arch foot to the risk of cracking. In order to prevent the occurrence of concrete cracking at the arch foots in service period, many suggestions for optimizing the design of the arch bridge have been reported during the past decades [3]. However, with the widely construction of girder-arch composite bridges using CFST arch ribs, it is found that cracking are commonly found on the surfaces of concrete at the arch foot joint zone [4]. Related studies revealed that despite the favorable capacity of the joint concrete in service period, the tensile stress 
induced by the pumping pressure of concrete infill in construction period cannot be ignored [5]. However, few studies have been focused on this issue.

The Liuxi River Bridge is a PC continuous girder-arch composite bridge under construction and located in Guangzhou, China. The CFST arch rib of this bridge is embedded in the PC girder and the arch foot is right above the pier. In order to prevent cracking of the concrete surrounding the CFST ribs, and in addition of improving the construction quality of the bridge, a comprehensive analysis involving the influence of pumping pressure of concrete infill during construction of the CFST is presented and discussed in this paper. The outcomes of this study can provide technical support for preventing the early cracking on the arch foot, which has significant contribution to the extensively application of this type of composite bridge.

\section{Method}

\subsection{Porotype bridge}

Liuxi River Bridge is a railway bridge that is under construction and located in Guangzhou, China. The bridge consists of a PC continuous box-girder and two CFST arch ribs. The arch ribs and box-girder were connected by two arch foots at the bridge supports. The span arrangement of the PC girder is $90 \mathrm{~m}+180 \mathrm{~m}+90 \mathrm{~m}$, with a deck width, a height at middle and root of PC girder of $14.2 \mathrm{~m}, 4.5 \mathrm{~m}$, and $10.0 \mathrm{~m}$, respectively. The cross-section of the PC girder is composed of single box separated in two cells. The thickness of top slab for box-girder is $0.42 \mathrm{~m}-1.02 \mathrm{~m}$, while the thickness of bottom slab for box-girder is $0.40 \mathrm{~m} \sim 1.50 \mathrm{~m}$. Fig. 1 shows the arrangement and configurations of the Liuxi River Bridge.

The arch ribs are in the structural form of CFSTs, and the rise of the arch rib is $36.0 \mathrm{~m}$. The cross-section of the CFST ribs is in the shape of dumbbell. Fig. 2 shows the geometric dimensions for the dumbbell section of the CFST arch rib. The steel cells are filled with normal concrete, with a target compressive strength of 55.0 MPa. Q345q-D grade steel is used for all steel members in the arch rib. The suspenders are made of steel cables, which have tensile strength of $1670.0 \mathrm{MPa}$. The yield strength of pre-stressed tendons used for PC girder is $1860 \mathrm{MPa}$.

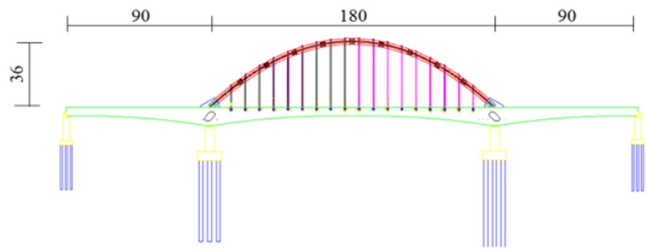

a) Vertical view

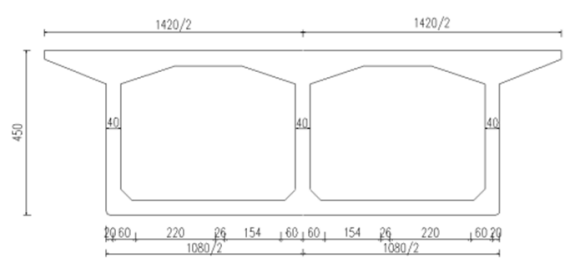

b) Cross-section of PC girder at span middle

Fig. 1. Configurations of Liuxi River Bridge (unit: $\mathrm{cm}$ )

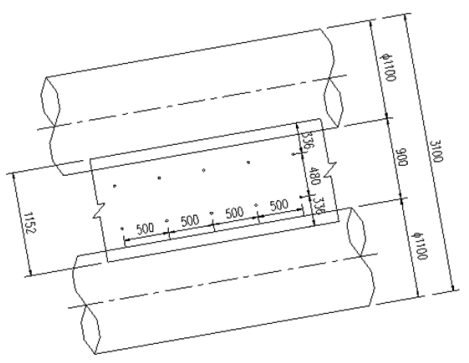

a) Segment of CFST arch rib

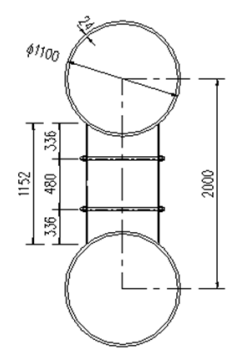

b) Cross-section of CFST arch rib

Fig. 2. Configurations of CFST arch rib (unit: $\mathrm{mm}$ )

The Liuxi River Bridge is a railway bridge. The density of the concrete and steel are $26.0 \mathrm{kN} / \mathrm{m}^{3}$ and $78.5 \mathrm{kN} / \mathrm{m}^{3}$, respectively. The linearly distributed load caused by the self-weight 
of steel rail, sleeper, ballast, protective layer, waterproof layer, triangle cushion layer, ballast proof wall, sidewalk, guardrail is $142.9 \mathrm{kN} / \mathrm{m}$. Vertical live load of the train: the longitudinal calculation adopts the medium - live load, and the double line is calculated by $90 \%$ of the total live loads.

\subsection{Finite element model}

Based on the arrangement and configurations of the Liuxi River Bridge, the arch foot between the supports and the arch ribs is isolated and numerically simulated. The segment of PC girder, and the concrete infill encased in the CFST ribs are modeled using solid elements. The steel tubes of CFST ribs are simulated using shell element. At the interface between PC girder segment and the CFST ribs, headed studs are installed. In the numerical model, nonlinear foot elements are utilized to model the tangents stiffness from these shear connectors. On the other hand, the normal constraint between the CFST rib and surrounding concrete is simulated through coupling the corresponding degrees of the associated nodes at the interface. The mapping hexahedron mesh was used to divide the cells, and the meshing size of the element is $45 \mathrm{~cm}$. The boundary at the bottom surface of PC girder segment is hinged constraint. The end section of PC girder and the CFST arch rib section are provided with yoke restraint. The force applied on these yoke restraints are obtained from system calculation using beam element for the Liuxi River Bridge. The solid local model for the arch foot is shown in Fig. 3.

According to the actual construction sequence, the concrete of the up and down chord tubes are pumped first, and the concrete of the webs between the up and down chord tubes is pumped after the strength of concrete in chord pipes reaches $90 \%$ of its design strength. Accordingly, the computation of the numerical model consists of two stages: the first stage simulates pumping concrete into the chord tubes, and the second stage simulates pumping concrete into the webs. Diagrams for load simulations in different stages are shown in Fig. 4.

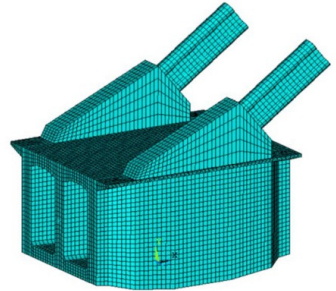

a) Element view of arch foot

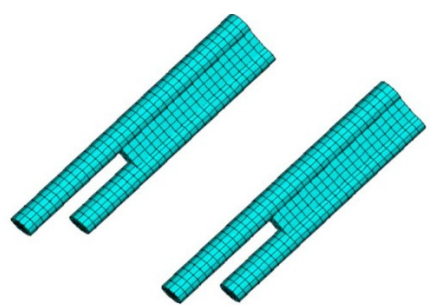

b) Element view of CFST ribs

Fig. 3. Structure drawing of finite element model

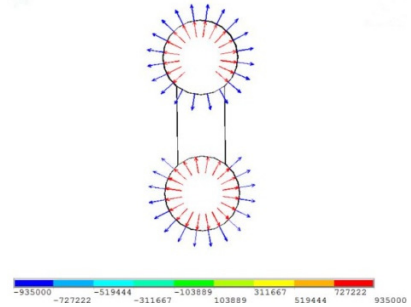

a) First stage

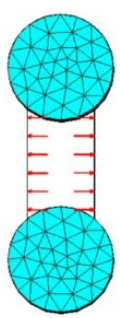

b) Second stage

Fig. 4. Pumping load simulation in finite element models

\section{Results and discussions}

The cracking of CFST arch foot is a key problem to the structural safety of CFST arch bridge, and the influence of pumping pressure of concrete infill on the cracking of arch concrete is significant. In this section, the local stress and deformation of each component of CFST arch foot at different construction stage is presented and discussed. 


\subsection{Results of first stage}

\subsubsection{Stress of each component}

Stress of steel tubes under the radial pressure of concrete infill is shown in Fig. 5. As can be seen, in the first stage of pumping concrete, the inner pressure exerts stress on the steel tube. The connection between the steel tube and the web is relatively weak. The maximum tensile stress of the arch rib steel tube is generated near the web between the up and down chord tubes, and the maximum value is $123.0 \mathrm{MPa}$. It is noted that the down chord tube is in compression, and the maximum compressive stress is generated at the lower side of down chord tube, and the maximum value is $-95.0 \mathrm{MPa}$.

Stress of PC girder segment under the pumping pressure of concrete infill is presented in Fig. 6 . As can be seen, during the first stage of pumping concrete, the pressure inside the tube produces radial stress on the up and down chord tubes, and the steel tube deforms. Meanwhile, the concrete of the outer arch foot is squeezed by the deformation of steel tubes. Similar to the distribution of major principle stress of steel tube, the tensile stress of concrete gradually increases from the arch foot to the vault. The maximum tensile stress of concrete occurs on the outside of the concrete near intersecting plane between the PC girder and the arch rib, with a maximum value of 3.6 MPa.

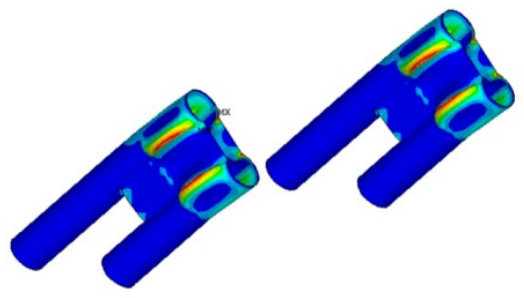

a) Major principle stress
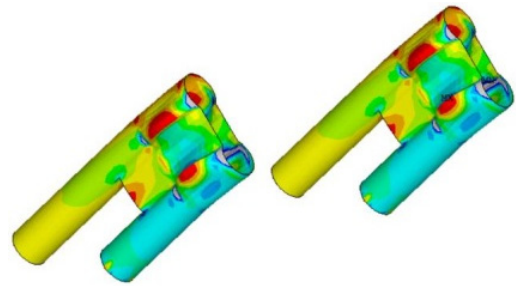

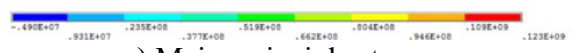

Fig. 5. Stress results of steel tubes

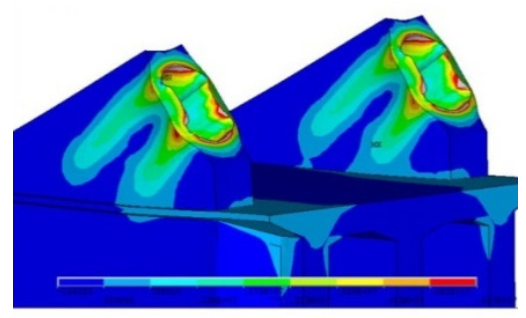

a) Outside surface

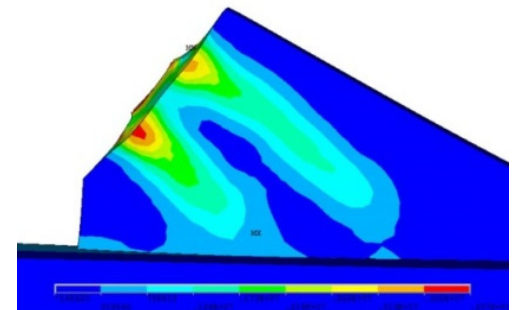

b) Inside surface

Fig. 6. Tensile stress of PC girder segment

\subsubsection{Deformation of each component}

The deformation of steel tubes and PC girder segment at the arch foot is shown in Fig. 7. As can be seen, the pumping pressure causes the tube expanded, and the maximum transverse displacement of the arch rib steel pipe is generated near the web of the chord tubes, with a maximum value of $2.4 \mathrm{~mm}$. Due to the self-weight of concrete infills, the steel tube is compressed along the arch axis and bent downward. The maximum vertical displacement of the arch rib is generated at the lower side of the down chord tube, with a maximum value of $1.9 \mathrm{~mm}$. On the other hand, the displacement of the outside concrete is greater than that on the inside. The maximum displacement of surrounding concrete occurs at the outside of the intersection plane between the PC girder segment and the arch rib, with a maximum value of $0.36 \mathrm{~mm}$. 


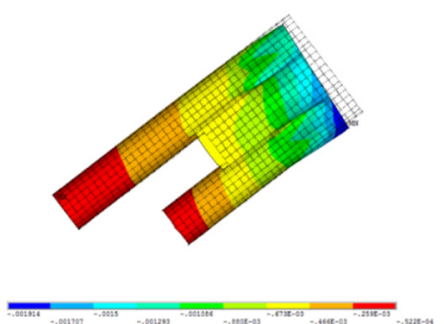

a) Steel tube

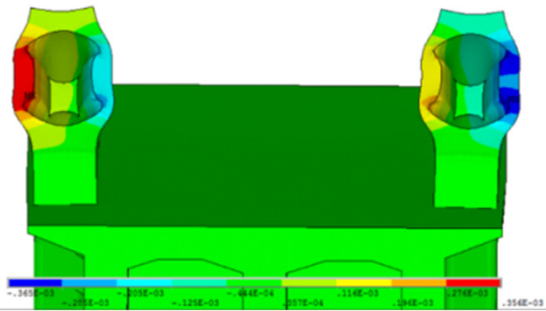

b) PC girder segment

Fig. 7. Deformation of arch foot

\subsection{Results of second stage}

\subsubsection{Stress of each component}

Stress of steel tubes at the second pumping concrete stage is shown in Fig. 8. As can be seen, in the second stage of pumping concrete, the chord concrete has been hardened, and the stress of the chord is barely influenced by the pumping pressure from web concrete. At this stage, the web was pressurized and deformed outward, and the maximum tensile stress of the web appeared at the center line of the web, with a maximum value of 88.7 MPa. Web tie bar effectively limited its own deformation, and reduced the first principal stress, with a maximum stress of $101.0 \mathrm{MPa}$.

Stress of PC girder segment at the second pumping concrete stage is shown in Fig. 9. As can be seen, the pumping pressure produces stress on the webs. Due to the side deformation of the tubes, the outer concrete is gradually squeezed. The tensile stress of concrete increases from the arch foot to the vault, and the tensile stress on the outside is slightly greater than that on the inside. The maximum tensile stress of concrete appears on the outside of the arch concrete, with a maximum value of $1.57 \mathrm{MPa}$.

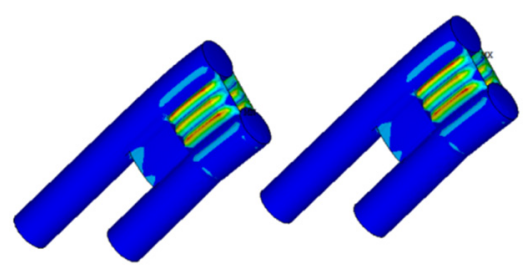

a) Major principle stress
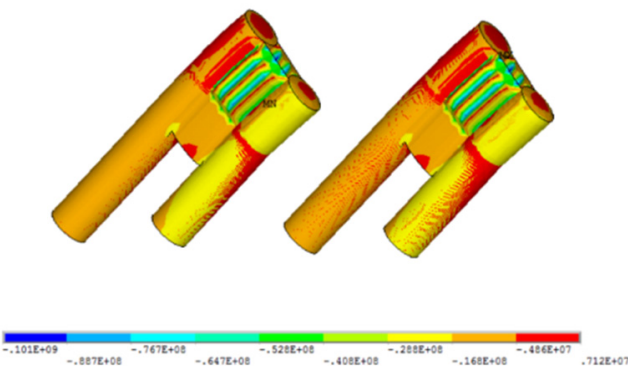

b) Minor principle stress

Fig. 8. Stress results of steel tubes

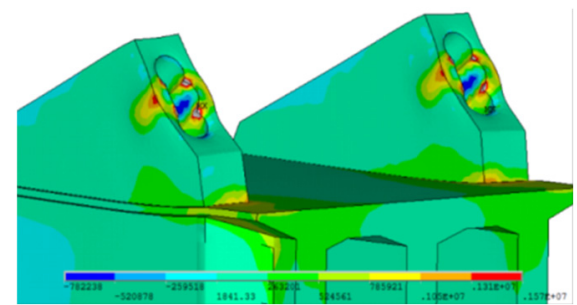

a) Outside surface

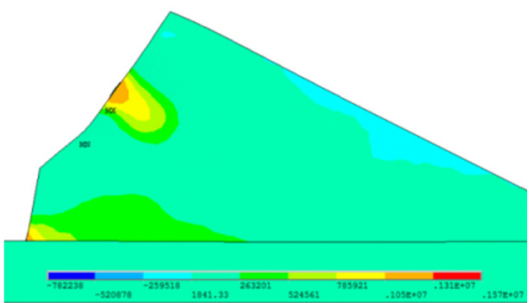

b) Inside surface

Fig. 9. Tensile stress of PC girder segment

\subsubsection{Deformation of each component}

The deformation of steel tubes and PC girder segment at the second pumping concrete stage is 
shown in Fig. 10. As can be seen, in the second stage of pumping concrete, the chord tube concrete has been hardened, and the pumping web concrete has little effect on the deformation of the tubes. The lateral wall of the arch rib web is pressurized and the maximum deformation is $0.63 \mathrm{~mm}$. Under the weight of arch rib steel tube and concrete, Steel tube and concrete infill are compressed along the arch axis, and arch rib bends downward. It is noted that the maximum vertical displacement appears on the lower side of the down chord tube, and the maximum value is $0.49 \mathrm{~mm}$. On the other hand, the displacement of outside concrete is greater than the inside concrete. The maximum lateral displacement of concrete occurs on the lateral side of the concrete near the intersection plane between the PC girder and the CFST rib, with a maximum value of $0.13 \mathrm{~mm}$.

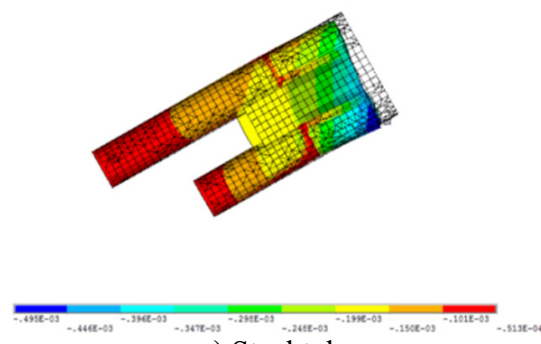

a) Steel tube

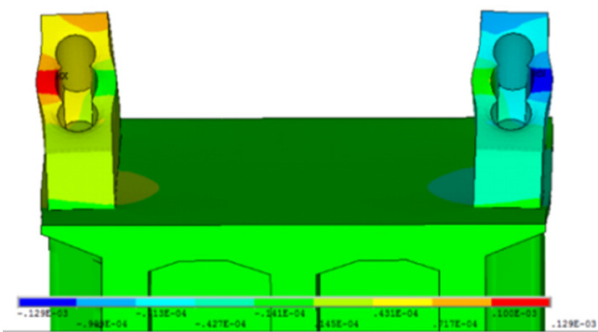

b) PC girder segment

Fig. 10. Deformation of arch foot

\section{Conclusions}

This paper examined the structural behavior of arch foot during construction stage, the conclusions can be drawn:

1) In the first stage of pumping concrete, under the radial stress induced by the pumping pressure, the maximum tensile and compressive stress in steel tubes are $123.0 \mathrm{MPa}$ and -95.0 $\mathrm{MPa}$, respectively, which are under the material allowable stress. The maximum tensile stress in surrounding concrete is $3.6 \mathrm{MPa}$, which is larger than the tensile strength of the concrete, indicating the PC girder would crack during this stage.

2) In the second stage of pumping concrete, the maximum tensile stress in steel webs are 101.0 $\mathrm{MPa}$, which is below the material allowable stress. The maximum tensile stress in surrounding concrete is $1.57 \mathrm{MPa}$. The PC girder is at a risk of cracking during this stage.

3) The displacement of the steel tube and concrete at the region of arch foot is small. The maximum displacement increments of steel tube at the first and second stages are $2.4 \mathrm{~mm}$ and $0.69 \mathrm{~mm}$, respectively. The corresponding increments for PC girder segment are $0.36 \mathrm{~mm}$ and $0.13 \mathrm{~mm}$, respectively.

\section{References}

[1] He S., Fang Z., Mosallam A. S. Push-out tests for perfobond strip connectors with UHPC grout in the joints of steel-concrete hybrid bridge girders. Engineering Structures, Vol. 135, 2017, p. 177-190.

[2] Yan B., Dai G. L., Guo W. H., Xu Q. Y. Longitudinal force in continuously welded rail on long-span tied arch continuous bridge carrying multiple tracks. Journal of Central South University, Vol. 22, Issue 5, 2015, p. 2001-2006.

[3] Zou C., Wang Y., Moore J. A., Sanayei M. Train-induced field vibration measurements of ground and over-track buildings. Science of the Total Environment, Vol. 575, 2017, p. 1339-1351.

[4] He S., Fang Z., Mosallam S.A., Ouyang Y., Zou C. Behavior of CFSC encased shear connectors in steel-concrete joints: push-out tests. Journal of Structural Engineering (ASCE), Vol. 146, Issue 4, 2020 , p. 04020015.

[5] He S., Mosallam S.A., Fang Z., Liu L. Structural evaluation of steel-concrete joint with UHPC grout in single cable-plane hybrid cable-stayed bridges. Journal of Bridge Engineering (ASCE), Vol. 24, Issue 4, 2019, p. 04019022. 